\title{
The Idea of Mass Culture in the Technologized Context of Lifelong Learning from the Philosophical Perspective of Ortega y Gasset
}

\author{
ILONA VALANTINAITE், ŽIVILE் SEDEREVIČIŪTĖ-PAČIAUSKIENE், \\ VAIDA ASAKAVIČIŪTE், VIDA NAVICKIENE் \\ Faculty of Creative Industries, Vilnius Gediminas Technical University, 26 Pylimo/1 Trakų Street, 00132 Vilnius \\ Email: ilona.valantinaite@vgtu.lt
}

\begin{abstract}
The article discusses consequences of increasing accessibility of education employing virtual learning environments. The main focus is laid on two consequences, i.e. on flourishing of mass-man and elimination of individual attitude. Seeking to ensure accessibility of education to everybody, equal conditions are introduced: technologization of the learning process through virtual learning environments leads to assurance of the level of convenient use, which diverts the attention from the essence, i.e. from the creation of elite culture in personality education. According to Ortega y Gasset, mass culture, information for the masses and environment overwhelm consciousness of an individual, who has lost his/her individuality, and irreversibly take an individual away from his/her interest in the meaning of existence. The article focuses on the technologization of lifelong learning development, its progressive and destructive aspects. Technologization seems to be an integral component of the system of education in the 21 st century. It also facilitates teaching/learning, makes it more attractive, accessible, convenient, individualised and efficient, although its efficiency and effectiveness are still questioned (Price, Kirkwood 2014; Englund, Olofsson, Price 2017). What factors encourage development and technologization of lifelong learning? What advantages and disadvantages of using virtual learning environments are distinguished by students and what does this presuppose? Does not this lead to flourishing of mass culture and mass-man education?
\end{abstract}

Keywords: Ortega y Gasset, mass culture, technologization, lifelong learning, student's attitude

\section{THE IDEAS OF ORTEGA Y GASSET IN THE CONTEXT OF INCREASING ACCESS TO LEARNING}

The beginning of the new millennium, which was marked by otherness, imposed the necessity and demand for technologization in education. The abundance of spaces and tools for communication as well as development of social networks, exceptional mobility of people, globalisation, openness of countries, common European Higher Education Area, rapid penetration of technologies into life and professional activity of every individual have opened up new opportunities and have brought limitations and changes simultaneously. 
This technological process that facilitates rapid economic progress has been obviously predetermining changes not only in social cultural values. This has also led to strengthening pragmatism, materialism, consumerism as well as to changes in education. Depersonalised technological processes have been gradually suppressing development of every young person's individuality and his/her interest in the existential problems of being.

Evaluating technical and cultural processes currently occurring in Western European society, the ideas of such representatives of culture philosophy from the turn of the 19-20th centuries as Karl Jaspers, Nikolai Berdyaev, Oswald Spengler, Albert Schweitzer, Antanas Maceina, Juozas Girnius and others have become particularly relevant. However, the thoughts of Ortega y Gasset, a Spanish cultural philosopher, have called for a specific attention. In his prominent work 'The Revolt of the Masses' the thinker elaborates on the ideas that are assumed as a revolt against the mediocrity stereotypes, which have been conquering the consciousness of mass-man deprived of individuality and have been undermining his/her concern about the meaning of existence (Asakavičiūtè 2014). Declaring the epoch of revolt of masses and the crisis of Western culture, Ortega y Gasset sought to awaken the human soul and to free the mind from the standards of universal thinking, to enhance the individuality, creativity as well as to develop his/her moral spirituality and consciousness to assume responsibility for own actions and life.

From the perspective of philosophy of history, the individuality and personality development, self-cognition and moral education were regarded as some of the most relevant issues discussed in the works of such prominent philosophers of antiquity as Socrates, Plato 'The Republic' and Aristotle 'Politics'. These problems were further analysed in the works written by philosophers of New Age Enlightenment: 'Emile or, on Education' (1979) by Jean-Jacques Rousseau or 'John Locke on Education' (1964) by John Locke and others. The work 'Education' (1960) by Immanuel Kant, where the German thinker stated that the biggest and most challenging problem that a person can dedicate himself or herself to is upbringing. In the process it is necessary not only to convey knowledge but also to build up an overall character of a person and his/her sense of duty. These thinkers and the ideas of their philosophy of education have become important milestones searching for the answers to the questions that have been emerging in the current society and the system of education.

At all times education and tolerance, equality, forbearance, communality, individualism and nationalism have been the issues of importance in Western Europe. In his life Ortega y Gasset actively participated in social, political and educative activities as a politician, philosopher, culture and art critic. He also joined European movements, which were led by people supporting liberalism against nationalism. However, he also claimed that the European identity is a paradox: its unity is grounded on pluralism (Taltavull 2017). The roots of such superficial contradictions lie in the individuality of each person: self-creation, self-education and choices determined by circumstances.

Establishment of the European Union, the Bologna process, the withdrawal of the United Kingdom from the EU and prospering of mass consumerist culture in particular made up the main reasons for choosing the perspective of Ortega y Gasset, a Spanish nurturer of ideas of philosophy of culture, was chosen for the analysis of the problem distinguished in the article. A big number of interpreters and critics have been fascinated by the works, talents, unique erudition and insights of Ortega y Gasset, who himself is also regarded as a world-famous philosopher, 'grandee of Spanish culture', whose life, creative activities and a clear position of a humanist are set as a model for intellectuals, thinkers, artists and even politicians in 
the majority of Western European countries (Asakavičiūtè 2014; Andrijauskas 2004). Ortega y Gasset exalted the creative potential lying in an individual. He aimed to educate and develop a new young generation, the representatives of which can result in revival and renewal of the Spanish culture. Ortega y Gasset notices that due to technological progress and influence of mass culture, a depersonalised, non-autonomous individual-consumer without any spiritual ambitions and ideals is steadily gaining ground. A person absorbed by a powerful stream of masses destroys his/her individuality and loses the possibility of independent thinking and making independent decisions. According to the philosopher, an authentic life requires personal efforts from the individual himself/herself to create and interpret the surrounding world rather than immerse into the systems of common thinking.

Thus, although technologization that emerged in the context of lifelong learning increases accessibility of learning content, it does not solve problems of autonomy and personality development. In fact, technologies eliminate that just simplifying the teacher-student relationship and turning it into transmission and receiving of information and adding variety to it with the help of gamified elements of motivation. The speed of information access mixed with the demand for constant entertainment and pleasure, which are characteristic of contemporary young people, call for a new approach both to the process of learning itself and to the technologies employed in this process. On the basis of Socrates' philosophy, the relevant challenges that occur in the learning and virtual learning environments are revealed. According to Socrates, development of individuality, virtues and self-knowledge are of utmost importance in the process of learning. Knowledge is not a thing, which can be passed from hands to hands. This process is much more subtle and requires special relations between the transmitter and the receiver. Technological processes make the transfer of knowledge highly mechanical and automated. However, Socrates states that education of a young person cannot do without individual efforts of a person himself or herself and without ethic value education. The basis of the Socrates' methodology was a dialogue, discussion and the authority of a teacher. The Socratic method is referred to as maieutics, i.e. the art of midwifery. Just as a midwife assists in the birth of a baby, Socrates made attempts to assist a young person in acquiring the right knowledge (Rybelis 1997). A person is not supposed to get the final answers immediately. It is necessary to search for and to find the truth, to learn to reason and draw conclusions. An individual direct dialogue between the teacher and the learner is necessary when the teacher is able to guide the learner, to notice his/her mistakes and to direct the learner's thinking towards the truth.

The new technologies become mediators between the teacher and the student and undoubtedly provide certain advantages at the same time imposing certain threats. Internet platforms establish favourable conditions for flexible learning not only conveying the learning material but also including students into interactive learning, exchange of experience and their evaluation (Ghamdi et al. 2016). Moreover, the learning process in the virtual environment changes transmission and reception of knowledge, criteria of quality or even of correctness (Cabada et al. 2017). There emerges a question whether virtual environments can completely change the personal teacher-student relation? As it has been mentioned before, the benefit of virtual environment is beyond doubts. On the one hand, its use in higher education institutions allows the teachers to create more flexible learning models and help students to take a more active role in the process of learning (Koh et al. 2015). The student-centred process of learning provides a student with conditions for independent learning (Edumadze et al. 2017). On the other hand, easily and quickly accessible learning material weakens the need 
of students to search, analyse, evaluate or choose. The philosophy of Socrates approaches striving for individuality and development of critical thinking as one of the most important goals of education and training. Uniform curriculum, the same deadlines for learning the material lead to unified thinking as well. According to S. Brookfield (2013), the conditions are established, which, empowering 'learners and self-directed learners, conjure up very similar images. The same threat of unification and levelling was distinguished by Ortega y Gasset in his analysis of consequences of booming technologies. Similar ideas may also be found in the work 'Culture and Ethics' written by A. Schweitzer (1989), where the author underlines that the institutions that are supposed to stimulate and develop individuality and spiritual life of society succumbed themselves to superficiality, what turned the society into a grey, monotonous and soulless one. Thus, an individual as if dissolves in an anonymous, collective consciousness and in an organisation, which possess pre-constructed models. Similar critical views were expressed by German thinker K. Jaspers in his book 'Man in the Modern Age' (2010). The author claimed that the modern word and technical dominance promote an increasing levelling, mass character and alienation of human soul.

In 'Emile or, on Education' (1979) J. Rousseau also raised the question about what education should be like and to what extent advancements in civilisation and technologies can contribute to education and upbringing of a young person. He took a naturalistic position and, not demanding to reject all the technological achievements, still stated that 'it is important to control them [advancements] and particularly the ones, which prevent us from being natural' (Ozmon, Craver 1996). Obviously, J. Rousseau linked naturalness with freedom and expression of individuality. Civilisation and its technical advancements pose a threat to prevail over the child's interests and the natural course of his/her development. Natural development and education are closely connected with the nature and considerable attention to the child's interests. The significance of individuality and virtues is emphasised in 'John Locke on Education' (1964), where philosopher John Locke claims that the soul of every individual is something special and differs from that of other people. There hardly can be two children, whose education could be carried out applying the same method. Thus, the prominent creators of philosophy of education emphasised how important it is to prevent the educational processes from being unified and depersonalised by technologies following the standard technical models.

Therefore, the question is formulated whether the personal search of a young individual and his/her personal attitudes remain and where they remain when learning occurs in the limited virtual environment? What influence does this make at the personal level of student personality education and what impact can be identified at the levels of community or the whole nation?

Every person's individual plan, actions and choices have influence on the general public opinion. Therefore, while pursuing the major goals, it is important to involve every person individually (Asakavičiūte 2014; Taltavull 2017). Both Aristotle and Plato questioned and analysed the relation between the individuality and society, i.e. how through strengthening of individuality to direct a person towards the common ideals such as the universal good. The reservoirs of social capital include different institutions (schools, churches, government organisations, political institutions), where traditional values are nurtured, and individuals are educated in the spirit of community. The more diverse the individuals within the society are, the bigger is the social capital they create (Kačerauskas 2019). According to philosopher Ortega y Gasset, 'I' refers to the personal project, which is developed and created depending on societal context or social origin. The future is the most important dimension of personal 
time because our behaviour is predetermined by the individual project. However, the past is as important because it shows us our boundaries, which we are supposed not to trespass while pursuing our goals. Each person is a member of a nation or community with his/her own impact on other members, who also contributes to shaping the common opinion of the whole nation. According to J. B. Taltavull (2017), nationalism is a process, where different territories and social groups integrate into the common project referred to as a nation.

Particularism, which is the opposite to nationalism, is seen as a situation, where the nation is disintegrated due to the projects possessed by territories and social groups. In more modern words, the nation is a well-structured public opinion. Hence, what public opinion is structured by contemporary documents regulating education and what is the attitude of students, who have been using virtual learning conditions predetermined by educational strategies?

\section{INCREASE IN ACCESS TO LEARNING AND ITS TECHNOLOGIZATION}

Lifelong learning is linked with equal opportunities, social cohesion and better quality of life, which establishes favourable conditions for successful functioning under conditions of growing competition and in environment of technologization (A Memorandum on Lifelong Learning 2000). Agreements in international educational policy are reflected in the national political decisions and those made by educational institutions, which, in the course of time, should be mirrored in the improving social and economic environment at the personal and national levels. Educational institutions apply new ways and systems of learning/teaching create conditions for every member of society to use learning opportunities while attaining individual life goals. The Berlin Communique (2003) calls for development of lifelong learning opportunities at higher education level, for improving accessibility of higher education according to individual needs of citizens. Ratifying the Bergen Communique (2005), countries have committed to making quality higher education equally accessible to all providing favourable conditions for students so that they can complete their studies without obstacles related to their social and economic background. In other words, increasing the availability of studies is one of the key conditions for improving the quality of higher education provided for in the official educational documents of European Union.

Overviewing the activities of 20 years of the Bologna Communiqué, the Paris Communiqué (2018) states that the main goal of Bologna process, i.e. to create a favourable and high quality area for learning/teaching, has been successfully implemented so far. Technologization and digitalisation of studies are linked to application of information technologies for achievement of educational goals. However, in her dissertation research, A. Volungevičienè (2008) stated that 'rapid development of new technologies frequently becomes an object of fascination, whereas pedagogical projecting of curriculum, often under influence of technological resources, loses the main idea' (Volungevičienè 2008: 5).

\section{THE ANALYSIS OF LEARNERS' ATTITUDE TOWARDS ADVANTAGES AND DISADVANTAGES OF USING VIRTUAL LEARNING ENVIRONMENTS IN THE CONTEXT OF ORTEGA Y GASSET'S IDEAS}

Seeking to identify how virtual learning environments are evaluated by students and what influence it has on culture as well as on the individual's personality and world-view, empirical research was carried out. The goal of the research was to reveal the compliance between 
the Ortega y Gasset's mass culture and the students' attitude towards application of virtual learning environments in the process of study. The research problem is formulated as a question: what is the attitude of students towards virtual learning environments as a study process that has been undergoing increasing technologization and how does this influence the personality development and the culture of certain society?

\section{THE RESEARCH METHODOLOGY}

The article presents the analysis of open-ended questions about the advantages and disadvantages of virtual learning environments. The research sample included 106 third-year university students of Lithuanian (85), Russian (12) and Polish (9) nationalities. The informants were 20-22 years old and the average of their academic achievements ranged from 6.7 to 10 points. Analysing the data, the answers of the informants were grouped according to the meaning and respective categories were created. On the basis of the distribution of students' opinion, the schemes were designed (Fig. 1). Three categories were distinguished among advantages of using virtual learning environments: aspect of convenience, aspect of independent learning and aspect of information quality (Fig. 1a). The answers about disadvantages of using VLE provided by the informants fell under five categories: aspect of information quality, personal aspect, communicative aspect, technical aspect and eliminated disadvantages (Fig. 1b).

The research disclosed that students prioritized the convenience and speed of using information: 'it is convenient to access the learning material just at home,' 'I am able to access the necessary information fast'. Seeking to ensure the assess to studies, the student is provided with convenience and the learning material is presented through the prism of the teacher. However, the student is as if deprived of the possibility of critical evaluation of situations, information as well as of well-grounded choices. In this way, the individuality of student is eliminated. At present the student prefers the online material over books: 'there is no need to go to the library', 'you do not need a heap of books'. A number of students in the research tend to print out the material presented by the teacher in the virtual environment and see this fact as a disadvantage of virtual learning environment: 'frequently the material has to be printed out'. This may

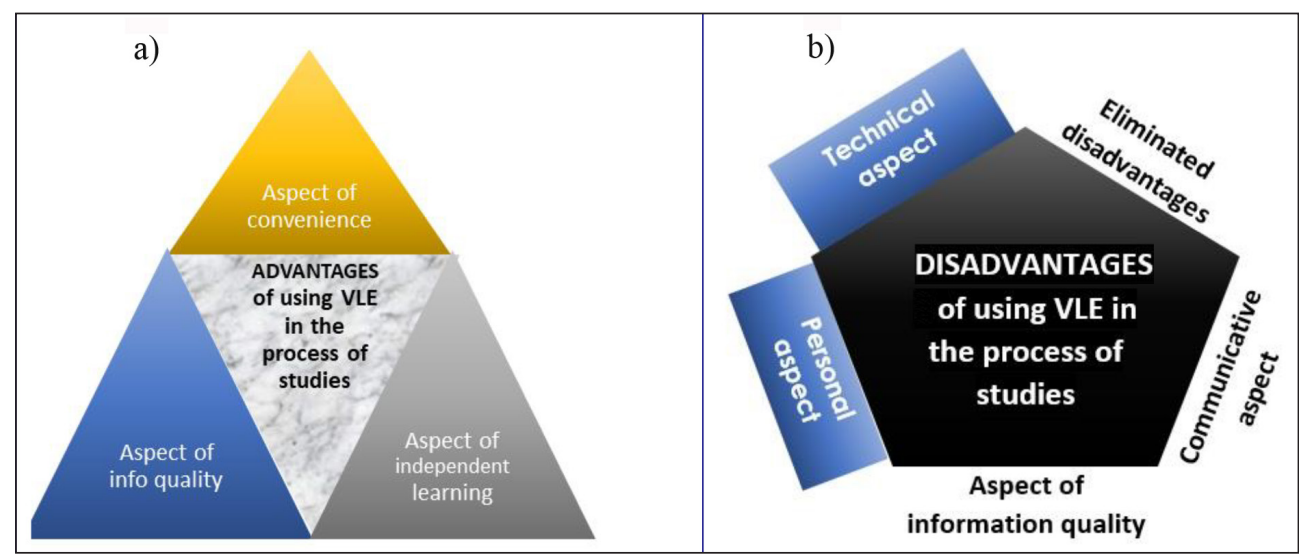

Fig. 1. The advantages and disadvantages of using VLE in the process of studies 
be predetermined by an individual learning style or different way of information processing. Students sometimes fail to conceptualize electronic study tools as suitable for learning and they do not perceive a virtual learning environment as a component of their real university (Butrimè, Zuzevičiūtè, Vitkutè-Adžgauskienė 2015).

The virtual learning environment, which is used by teachers, give the students a choice of where, when and what to learn: 'it is convenient to use because I can access it any time' (Fig. 1a). University students, who tend to plan their time individually, appreciate the convenience of studying and possibility of compensating academic classes in other ways, i.e. using virtual learning environments. Although the material is claimed to be reliable as it has been selected and sorted out by the teacher and can be used, analysed and applied easily ('it is very useful because the lecturer presents the material, which is appropriate and necessary') (Fig. 1a), some informants doubt the reliability of the information presented to them ("not all the provided information is reliable') (Fig. 1b). This may imply critical thinking but the results also showed that not all the students possess the necessary ability to select information, even if the information has already been selected and grouped: 'sometimes it is difficult not to get lost in the sea of information', 'there is a lack of human explanation'.

Thus, the analysis of received research data from the philosophical perspective of Ortega y Gasset confirms that technologically empowered convenience has been increasingly suppressing students' individuality and turning them into passive information users, who are referred to as mass people by the Spanish philosopher. In 'The Revolt of the Masses' (1993) Ortega y Gasset applies a big number of negative concepts seeking to define the personality and a way of living of mass-man. Such a person disregards any authorities, is full of pride, considers only his/her own opinion and is not eager to obey. He or she is a consumer, who 'uses here and now' and does not feel any gratitude or responsibility. And the philosopher adds that mass-people are 'spiritual paupers' because they "are hungry for various pleasures, decisively impose their will on others, refuse to help or serve other people, disobey everybody and are concerned only about themselves, their desires and wardrobe' (Ortega I Gasetas 1993). It is understandable that such a young person, who lacks self-criticism and does not require anything from himself or herself, is difficult to manage and educate. Incapability to open to another person and to help him or her shows alienation and egoism of a mass-man as well as degradation of his spirit and a very narrow world-view. Seeking to better understand the research data, it is also important to note that Ortega y Gasset divides Western European society into two layers, i.e. into mass as a passive consumerist majority, and spiritual elite, as an active creative minority. Such a rather radical division of society is not qualitative stratification into social classes. The criteria applied by the philosopher classifying all the members of society into two groups the mass and the spiritual elite refer to inner qualities of personality: self-consciousness, mentality, psychology, a way of life, principles of behaviour and value orientations (Asakavičiūte 2014, Andrijauskas, 2004). Hence, the aforesaid states are reflected not only in the human consciousness, psychology and world-view but also in the whole society and culture.

On the contrary, Ortega y Gasset refers to the spiritual elite as to dignified people, who are demanding of themselves. This is a feature of a dignified person. A dignified individual does not succumb to emotional desires and strives for self-control and cognition. The spiritual elite fulfil themselves serving others, authorities and God. Such a person is full of inner energy, takes a path of self-creation and spiritual development. A person from the spiritual elite is a creator of the self and environment and that of public welfare. It is 
a person, who feels the need for continuous improvement and lifelong learning. Namely such people are necessary for society because development of such abilities and values is necessary not only for the future welfare and society but also for the person himself or herself because, according to Ortega y Gasset, life always emerges as a problem and every person has to learn to solve this problem himself or herself. Thus, from the comparative aspect, a representative of mass culture acts in accordance with stereotypes of mass psychology, which promote inertia, passiveness and stagnation of human existence, whereas the spiritual elite consists of active creators pursuing ideals. The philosopher Ortega y Gasset discloses a radical difference and gap between the mass-man culture and the spiritual elite culture.

The ideas of Spanish philosopher are well-illustrated by the following contradictions as well. The ministers of the countries-participants in the Yerevan Communique (2015) were proud to have succeeded in creating European Higher Education Area (EHEA), where the countries are united by common goals, commitments and share common understanding of quality. The member countries apply common tools for quality assurance. Despite the indicated achievements, it was recognized that 'implementation of the structural reforms is uneven and the tools are sometimes used incorrectly or in bureaucratic and superficial ways' <...> Today, the EHEA faces serious challenges. It is confronted with a continuing economic and social crisis, dramatic levels of unemployment, increasing marginalization of young people, demographic changes, new migration patterns, and conflicts within and between countries, as well as extremism and radicalization' (Yerevan Communique 2015: 1). The situation may be explained employing the acting of masses and spiritual elite as well as predominance of masses, which were distinguished by Ortega y Gasset. Since priorities of mass-people are to take and consume, they care only about their benefit and they are not able to create and pursue high ideals. The current situation allows concluding that in higher education masses have more weight than the spiritual elite. As long as conditions to modify the very personality are not established, the international educational goals, which may lead to creation of more progressive society, can be hardly attained.

Currently Europe is facing numerous challenges: unemployment, social inequality, migration problems, violence, etc. Higher education is expected to play a crucial role in not only providing solutions to the problems of importance to society but also educating young generation with right virtues. Such expectations might be fulfilled if only the predominance of spiritual elite was established in higher education. Socrates, Plato and Aristotle, the aforesaid first philosophers of antiquity, emphasised that the society needs not only a well-trained and educated member but also a good virtuous person, who strives for and understands the significance of commitment and education (Plato 2003; Aristotle 2000). So far, the growth of personality, spiritual values as well as an individual teacher-student relation that shapes the personality have been neglected in the relevant educational documents. According to the data of the World Competitiveness Survey conducted by the World Economic Forum annually, 'Lithuania is favourably assessed in areas such as higher education and vocational training, infrastructure and technological readiness. However, the overall quality of education, the quality of management training and staff training are not seen quite as well' (Lithuania's Progress Strategy 'Lithuania 2030', Annex 1, Point 11).

Political decisions shape the environment of studies, where the participants in the process of education act. In his work 'The Theme of Our Times and Other Essays' (1999) Ortega y Gasset raised the questions what the university should be like and what its mission is. $\mathrm{He}$ stated that science is a significant core of university but scientice is not merely transmission 
or teaching of knowledge. 'Science is creation' and it has to be constantly linked with the life and the present of an individual. 'Therefore, the primary and main function of the university mission is teaching the great cultural disciplines' (Ortega y Gasset 1999: 217), such as philosophy or sociology, what would contribute to raising the mediaocracy to the elite heights.

Moreover, the aforesaid philosopher emphasised the necessity for the state to involve in reforms of universities and education. The adopted laws and implemented reforms in the process of education have to ensure education of a free, mature, creative personality that consciously creates or chooses the good. It should be noted that political ideas in practical activities lead to certain inconsistencies ignoring of which produces results that are not in line with the strategical goals. While increasing accessibility of studies and developing lifelong learning ideas, attempts are made to improve the life quality, social and economic welfare, to increase the country's competitiveness and others. However, mass-man culture, which promotes copying, imitation and blind adoption of imposed stereotypes and life standards, has been created instead. Therefore, the analysis may be finished with the statement of the famous Spanish philosopher of culture, who points out that Europe will reach a deadlock, if its destiny does not fall into the hands of people, who are deeply aware of the importance of developing real values and spiritual ideals.

\section{CONCLUSIONS}

The analysis of the mass theory of Ortega y Gasset calls for a serious consideration of the existential situation of the personality of young individual at present and destructive possibilities of modern technologies and mass media to unify unique abilities of an individual and to suppress his/her creative powers. The idea of lifelong learning encourages the processes of technologization but too strong concentration on technological solutions and methods may delay the very idea of introduction of e-studies. The conducted qualitative research and the analysis of its data reveal that the innocently unified level of convenience for everybody allows attaining the outcomes provided for in the educational strategies, i.e. education becomes conveniently accessible to all. However, Ortega y Gasset's critics of mass culture encourage serious reconsideration of one-sided introduction of technologies into the process of education. If the main focus of studies is diverted from the personality growth, building up of individual's values and world-view to technologization exclusively, a passive consumer society, whose members are not ready to assume responsibility and do not justify the essential idea of higher education, is developed. The strategy for harmonisation of human resources firstly requires a non-material value-based attitude towards higher education. Appropriate distribution of responsibilities creates conditions to be demanding firstly for themselves and to engage in self-creation. A creating individual creates culture, where other personalities are also formed.

Received 5 May 2020

Accepted 1 June 2020

\section{References}

1. A Memorandum on Lifelong Learning. 2000. Available at: https://uil.unesco.org/i/doc/lifelong-learning/ policies/european-communities-a-memorandum-on-lifelong-learning.pdf

2. Andrijauskas, A. 2004. 'J. Ortega y Gasseto raciovitalizmas', iš Kultūros, filosofijos ir meno profiliai (RytaiVakarai-Lietuva). Vilnius: Kultūros filosofijos ir meno institutas, 347-361.

3. Aristotle. 2000. Politics. New York: Publisher Dover Publications INC.

4. Asakavičiūtè, V. 2014. 'An Opposition between Mass Individual and Spiritual Elite in Ortega Y Gasset's Life Philosophy', LOGOS 79: 20-32. 
5. Brookfield, S. 2013. Powerful Techniques for Teaching Adults. San Francisco: Wiley.

6. Butrimè, E.; Zuzevičiūte, V.; Vitkutè-Adžgauskienè, D. 2015. 'Are Universities Able to Use the Potential of Students - Digital Natives?', Verbum 6: 233-247.

7. Cabada, R. Z.; Estrada, M. L. B.; Hernández, F. G.; Bustillos, R. O.; Reyes-García, C. A. 2017. 'An Affective and Web 3.0-based Learning Environment for a Programming Language, Telematics and Information 35(3): 611-628.

8. Communique of the Conference of European Ministers Responsible for Higher Education, Bergen, 19-20 May 2005. Available at: https://www.smm.lt/uploads/documents/Papildomas\%20meniu2/Bolonijos_procesas/ Bergen_communique.pdf

9. Communique of the Conference of Ministers Responsible for Higher Education in Berlin on 19 September 2003. Available at: https://www.smm.lt/uploads/documents/Papildomas\%20meniu2/Bolonijos_procesas/ Berlin_communique.pdf

10. Edumadze, J. K.; Ogoe, J. I.; Essilfie, G.; Edumadze, G. E.; Graham, R. E. 2017. 'E-learning at the University of Cape Coast, Ghana - Are Our Distance Education Students Technologically Ready?', The Online Journal of Distance Education and e-Learning 5(1): 47.

11. Englund, C.; Olofsson, A. D.; Price, L. 2017. 'Teaching With Technology in Higher Education: Understanding Conceptual Change and Development in Practice', Higher Education Research o Development 36(1): 73-87.

12. Ghamdi, A.; Samarji, A.; Watt, A. 2016. 'Essential Considerations in Distance Education in KSA: Teacher Immediacy in a Virtual Teaching and Learning Environment', International Journal of Information and Education Technology 6(1): 17-26.

13. Yerevan Communique 2015. Available at: https://www.ehea.info/media.ehea.info/file/2015_Yerevan/70/7/ YerevanCommuniqueFinal_613707.pdf

14. Jaspers, K. 2010. Man in the Modern Age. London: Routledge.

15. Kačerauskas, T. 2019. 'Creative and Social Capital: Concepts, Problems and Contradictions', Sociologia. Bratislava: Slovak Academic Press 51(3): 235-249.

16. Kant, I. 1960. Education. USA: University of Michigan Press.

17. Koh, J. H. L.; Chai, C. S.; Benjamin, W.; Hong, H. Y. 2015. 'Technological Pedagogical Content Knowledge (TPACK) and Design Thinking: A Framework to Support ICT Lesson Design for 21st Century Learning, The Asia-Pacific Education Research 24: 535-543.

18. Lithuania's Progress Strategy 'Lithuania 2030'. Available at: https://www.unesco.org/education/edurights/ media/docs/2953897c103c13043bfabea84b716ae2f8c82f47.pdf

19. Locke, J. 1964. John Locke on Education. New York: Teachers College Press, Columbia University.

20. Ortega y Gasset, J. 1993. Masiu sukilimas. Vilnius: Mintis.

21. Ortega y Gasset, J. 1999. Müsų laiku Tema ir kitos Esè. Vilnius: Vaga.

22. Ozmon, H. A.; Craver, S. M. 1996. Filosofiniai ugdymo pagrindai. Vilnius: Leidybos centras.

23. Paris Communique, Paris, May 25th 2018. Available at: https://www.smm.lt/uploads/documents/ Papildomas\%20meniu2/Bolonijos_procesas/EHEAParis2018-Communique-final.pdf

24. Plato. 2003. The Republic. New York: Cambridge University Press.

25. Price, L.; Kirkwood, A. 2014. 'Using Technology for Teaching and Learning in Higher Education: A Critical Review of the Role of Evidence in Informing Practice', Higher Education Research \& Development 33(3): 549-564.

26. Rybelis, A. 1997. „Sokratas ir jo filosofija: žinau, kad nieko nežinau“, iš Ksenofontas. Atsiminimai apie Sokrata. Vilnius: Pradai.

27. Rousseau, J. 1979. Emile or, on Education. USA: Basic Books.

28. Schweitzer, A. 1989. Kultūra ir etika. Vilnius: Mintis.

29. Volungevičienè, A. 2008. Nuotolinio mokymo(-si) turinio kokybés reflektyvaus vertinimo projektavimas. Disertacija. Kaunas: Vytauto Didžiojo universiteto leidykla. 
ILONA VALANTINAITE், ŽIVILE் SEDEREVIČIŪTE்-PAČIAUSKIENE், VAIDA ASAKAVIČIŪTĖ, VIDA NAVICKIENE்

\title{
Masès kultūros idẻjos technologizuojamame mokymosi visą gyvenimą kontekste iš Ortegos y Gasseto filosofinès perspektyvos
}

\begin{abstract}
Santrauka
Straipsnyje aptariamos švietimo prieinamumo didinimo, naudojant virtualias mokymosi aplinkas, pasekmès - masès žmogaus suklestèjimas ir individualaus požiūrio eliminavimas. Siekdami padaryti švietimą prieinamą visiems, suvienodiname sąlygas: technologizuodami mokymosi procesą per virtualias mokymosi aplinkas suteikiame patogumo naudotis lygí, kuris nukreipia dèmesį nuo esmès - asmenybių ugdymo elito kultūros kūrimo. Pasak Ortegos y Gasseto, masinè kultūra, masėms skirta informacija ir aplinka užvaldo individualumą praradusio masès žmogaus sąmonę ir negrižtamai nutolina žmogaus domejjimąsi būties prasme. Straipsnyje analizuojama mokymosi visą gyvenimą plètotès technologizacija, jos progresyvūs ir destruktyvūs aspektai. Technologizacija, atrodytų, neišvengiama XXI amžiaus pradžios švietimo sistemos dalis. Technologizacija palengvina mokymą(si), daro ji patrauklesni, prieinamesnị, patogesnį, individualesni efektyvesni tačiau vis dar kyla abejonių dèl jos veiksmingumo ir efektyvumo (Price, Kirkwood 2014; Englund, Olofsson, Price 2017). Kokie veiksniai skatina mokymosi visą gyvenimą plètotę ir technologizaciją? Kokie studentų išskiriami privalumai ir trūkumai naudojant virtualias mokymosi aplinkas ir ką tai suponuoja? Ar tai nèra masių kultūros suklestėjimas ir masių žmogaus ugdymas?
\end{abstract}

Raktažodžiai: Ortega y Gasseta, masių kultūra, technologizacija, virtuali mokymosi aplinka, mokymasis visą gyvenimą, studentų požiūris 